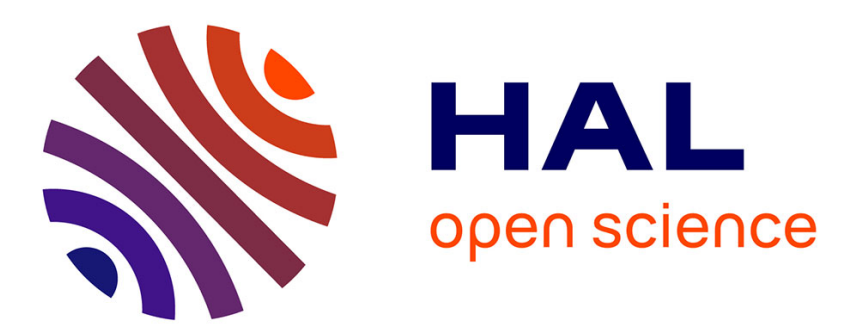

\title{
Beyond consensus: ideas and advocacy coalitions around cash transfer programs in Brazil and Mexico \\ Carla Guerra Tomazini
}

\section{To cite this version:}

Carla Guerra Tomazini. Beyond consensus: ideas and advocacy coalitions around cash transfer programs in Brazil and Mexico. Critical Policy Studies, 2017, 13 (1), pp.1 - 20. 10.1080/19460171.2017.1352529 . halshs-01811049

\section{HAL Id: halshs-01811049 \\ https://shs.hal.science/halshs-01811049}

Submitted on 10 Apr 2019

HAL is a multi-disciplinary open access archive for the deposit and dissemination of scientific research documents, whether they are published or not. The documents may come from teaching and research institutions in France or abroad, or from public or private research centers.
L'archive ouverte pluridisciplinaire HAL, est destinée au dépôt et à la diffusion de documents scientifiques de niveau recherche, publiés ou non, émanant des établissements d'enseignement et de recherche français ou étrangers, des laboratoires publics ou privés. 
The final version was published online in Critical Policy Studies, 8 August 2017.

https://www.tandfonline.com/doi/abs/10.1080/19460171.2017.1352529

To cite this article:

Carla Tomazini (2019) Beyond consensus: ideas and advocacy coalitions around cash transfer programs in Brazil and Mexico, Critical Policy Studies, 13:1, 23- 42.

DOI: $10.1080 / 19460171.2017 .1352529$

\title{
Beyond consensus: ideas and advocacy coalitions around cash transfer programs in Brazil and Mexico
}

\author{
Carla Tomazini \\ Political Science Department, University of Versailles Saint-Quentin-en-Yvelines, Versailles, France
}

\section{KEYWORDS}

Conditional cash transfer programs; advocacy coalitions; Mexico; Brazil; social assistance; human capital; institutional change

\begin{abstract}
How do new social policies emerge? The literature on developed countries has put forth important assumptions about changes in welfare policies, particularly building on the work of EspingAndersen. However, discussion of social protection policies in middle-income countries underscores that rising policy innovations derive mostly from exogenous dimensions (external ideas and factors). In examining Mexico's Oportunidades and Brazil's Bolsa Família, one main question is addressed: What causal mechanisms underlie the rise of policy innovations that are not derived from exogenous dimensions? This article proposes moving beyond the argument in which international influence versus domestic politics are in opposition, and it suggests instead to compare empirical cases in different contexts, specifically by exploring the process of endogenous institutional changes using the example of conditional cash transfer (CCT) programs. By exploring recent theoretical contributions to institutional changes, the article identifies two critical aspects: (1) the rise of a dominant advocacy coalition favoring an ideology that promotes human capital as a key factor in the formation of national CCT programs in Brazil and Mexico; and (2) advocacy coalitions achieve similar results in terms of institutional changes in Brazil and Mexico, despite having different strategies and patterns of change.
\end{abstract}

How do new social policies emerge? How can we explain the rise of policy models? The literature on developed countries has put forth important assumptions about changes in welfare policies by grouping social policies into distinct regimes or spheres of the welfare state (Esping-Andersen 1990; Huber and Stephens 2001). However, changes to social protection policies in middleincome countries - particularly in Latin America over the last few decades - present a major challenge for welfare state researchers (Carnes et al. 2007). By making use of the Advocacy Coalition Framework (ACF) (Sabatier and Jenkins-Smith 1993; Sabatier 1999) and recent theoretical contributions to institutional changes, this article allows for deeper understanding of 
a recent Latin-American social policy innovation (conditional cash transfer [CCT] programs), especially regarding the ideas and advocacy coalitions that were mobilized.

Regarding developing countries, two main patterns of analysis may be identified in the relevant literature with some overlap between them. On the one hand, scholars have highlighted many cases in which institutional changes in Latin America are shaped by external ideas and exogenous factors such as social crises, political-economical upheavals, exogenous shocks and the influence of powerful international actors (Weyland 2004; Weyland 2006). The main argument is that decision-makers often take inspiration from external ideas and models; thus, institutional change and innovation often proceed in waves. On the other hand, political models, blueprints and consensus seem to arise and, consequently, endogenous dynamics are often relegated to the background.

In many cases, however, exogenous dimensions and transnational ideas are important, but they do not provide sufficient explanations. This is the case of CCT programs, assistance programs for poor families on the condition that they encourage their children to seek education and attend health centers. They characterize a noteworthy case of the endogenously determined creation of an institution. Brazil's and Mexico's national programs are the only two CCT programs that can be considered locally rooted, in the sense that they were originally designed in parallel and financed without the support of international organizations (Handa and Davis 2006). CCTs have been modeled and implemented in almost every Latin American country over the recent decades (ECLAC 2017). In Brazil and Mexico, the pioneers and the two most celebrated federal CCT Progresa-Oportunidades-Prospera ${ }^{1}$ and Bolsa Escola, the predecessors of Bolsa Família provided benefits to approximately 25 percent of the national populations (MDS 2017; SEDESOL 2017). Regional and international consensus building around these programs was quite rapid, and these programs have been ranked by international organizations as being among the most supported state projects (Hall 2006; Handa and Davis 2006).

Why do dissimilar countries create similar policy innovations? What causal mechanisms underlie the rise of policy innovations that are not derived from exogenous dimensions? Institutional analysis from a gradualist perspective of change provides one possible key to understanding, since it sheds light on the rationale of the actors and on the ways in which they bring about institutional change (Mahoney and Thelen 2010; Streeck and Thelen 2005). From this perspective, institutions do not reveal the exact purposes of the triumphant actors and coalitions which manoeuver them. The ACF, developed by Sabatier and Jenkins-Smith (1993) and Sabatier (1999) offers a further possible approach for considering the ideas and coalitions that mobilized at the origin of a policy model. This article proposes moving beyond the opposing international influence versus domestic politics argument and to instead compare empirical cases in different contexts, specifically by exploring the process of endogenous institutional change using the example of CCT programs.

\section{Inquiring about CCT origins: ambiguous consensus}

Contrary to the consensual reception of CCT programs, this article proposes reexamining the nature of this 'model'. Whereas the majority of actors who are concerned with social assistance agreed with the new CCT policies, they did so for reasons that were often different and sometimes contradictory. The development of CCT in Brazil and Mexico can be considered the result of a political compromise or an 'ambiguous agreement' (Schickler 2001; Palier 2002), since the actors involved agreed upon the policy instruments but not the goals.

The following sections describe the three advocacy coalitions that participated in the CCT subsystems ('unconditional income', 'human capital' and 'food security'). The article then examines how the CCT subsystems have changed through the combined actions of these different 
coalitions. Finally, it addresses the factors that led to the consolidation of positions favoring human capital (which were designated here 'pro-human capital') in the subsystem. Those factors include institutional structure, political compromises and struggles among the domestic actors.

In this article, I show that the social assistance reforms that Brazil and Mexico implemented throughout the 1990s were the result of gradual and transformative change. Two primary modes of change were found: layering and displacement. With layering, the old institution remains in place, but it is merged with new institutions, rules and amendments that over the long run alter the rationale of the original core policy (Schickler 2001; Thelen 2003; Mahoney and Thelen 2010). Lacking the capacity to change the original rules, institutional challengers adopt a subversive attitude: they work within the existing system but undermine previous arrangements as more and more actors defect to the substitute institutions. With displacement, the old institution and the existing rules are gradually replaced by new ones. In this mode, change agents often adopt an insurrectionary strategy: they actively mobilize against existing institutions or rules, which incurs a loss for institutional defenders. The central hypothesis is that institutional changes that lead to the creation of CCTs in Brazil and Mexico are not part of the same underlying process but instead arise from different causal mechanisms which evolve in a way that favors one specific advocacy coalition (pro-human capital).

\section{ACF: actors gathered around beliefs}

In order to examine how CCT programs have emerged, I first process trace the development of CCT programs in both countries. Policy developments from 1991 to 2006 were reconstructed on the basis of written sources and interviews with people who were active in the CCT subsystems during that period. The first source comprised articles on CCT formulations and developments from daily Brazilian, Mexican, and international newspapers published between 1991 and 2006.

The second data source comprised semi-structured interviews $(n=51)$ with people involved in promoting the adoption of federal CCT or, more broadly, who were working on the matter at the state level. ${ }^{2}$ I interviewed officials and former officials of the relevant ministries and responsible agencies, a special assistant to the president, senators, representatives, researchers, technicians and NGO stakeholders, among other people. I asked about the actions that led to adoption of the $\mathrm{CCT}$, their roles in the process and their efforts to influence any policies, disagreements and groups that they could identify. They were also questioned about changes to the CCT subsystem that took place between 1991 and 2006. The third source of data was government documents, transcriptions of parliamentary debates and references from published and gray literature $(\mathrm{n}>$ 200), all of which were related to the issue of Brazilian and Mexican CCT programs. Using NVivo software, I conducted a content analysis of the material based on node hierarchies. The actors were then placed according to operationalized criteria (deep beliefs and policy beliefs, secondary beliefs). Although the official documents and governmental bulletins do appear to mask changes in order to build a political consensus, they usually express distinct positions, which illustrate the dividing line between coalitions.

Within the ACF, a subsystem/domain is defined as the interaction of formal and informal actors from different institutions who actively seek to influence governmental decisions in a specific policy area (Sabatier and Jenkins-Smith 1993; Sabatier 1999). The values and beliefs that are shared by each coalition exist on three levels: a fundamental core of values (deep core), inherent beliefs regarding the public policy subsystem (near core) and secondary aspects related to the details of public policy programs (secondary beliefs). Sabatier and Weible (2007) have argued that in order to identify at least two coalitions, one needs to demarcate and distinguish two or three policy core beliefs. Thus, this research identified the various belief subsystems based upon the policies within the subsystems and upon a review of the primary and secondary sources. The deep core and policy core beliefs that are relevant to this study can be found in Table 1 . 
Based on these assumptions and according to the values and perceptions of poverty, three main advocacy coalitions can be identified in the debate over introducing CCT programs (Tomazini 2013; Tomazini 2010). They coalesce around the concepts of 'unconditional income', 'human capital' and 'food security'. The dominant and most representative coalition in both countries is the 'pro-human capital' coalition. The 'pro-human capital' coalition is prevalent in the subsystems studied here, and it has managed to make the beneficiaries of cash transfers subject to fulfilling certain conditions such as attending school and visiting health centers. Their focus is on breaking the cycle of inter-generational transmission of poverty. Operating under the belief that human nature is inherently lazy, the transfers thus act to complement and not substitute individual efforts (Levy and Evelyne 2005, 60). Market freedom and autonomy represent the core beliefs of actors in this coalition. They believe that it is necessary to provide the populations with a minimum of resources, which they can then use in order to earn an income. With regard to welfare policies, cash transfer programs are prioritized because they target future generations, i.e. families with children. Indeed, CCT programs aim to respond to immediate economic distress in the hope of helping people rise out of poverty (Brière and Rawlings 2006). The policy core values of this coalition are based on the idea that 'children with better health and higher nutritional intake have better educational performance than sick and malnourished children, and have better earnings in the future' (Cohen and Franco 2006). Their members share the belief that the deprivation of scholarly knowledge and medical assistance makes poor people economically less productive. Unlike the means-tested minimum income in Europe that helps people integrate into the labor force, the minimum income in Latin America took the form of school and health conditionalities, as it was driven by the goal of activating human capital.

The 'pro-human capital' coalition consists of mostly professional networks (politicians and technocrats at different federal levels) who seek to ensure that social assistance programs are managed more efficiently than the previous ones. Several policymakers joined the offices that were responsible for CCT in the Brazilian and Mexican Ministries of Social Development, and they centralized many decisions and insulated these programs from other assistance programs. Beyond considerations of electoral gain, politicians (of both the executive and legislative institutions) have remained committed in their belief that conditional cash programs provide the best solutions for alleviating poverty. This coalition further includes nonprofit organizations, think tanks, universities that conduct policy research related to CCT and international organizations such as UNESCO, UNICEF, the United Nations Development Fund and the WB, among others. The press also represents an important stakeholder in this coalition. It focuses attention on issues of monitoring, compliance and enforcement of conditionalities over time - as demonstrated in the Brazilian case by Lindert and Vincensini (2010). Cristovam Buarque (Brazil) ${ }^{3}$ and Santiago Levy (Mexico) ${ }^{4}$ are two of the leading figures in developing CCT programs. They belong to the pro-human coalition and are the founders of, respectively, Bolsa-Escola and Progresa.

\section{Table 1.}

The 'pro-unconditional income' coalition is narrower and comprises politicians and some researchers who are mostly economists and social workers. The core values of this coalition are based on the deep belief that human beings are naturally inclined to seek better living conditions. The main values they espouse are market freedom and equality. Members of the coalition believe that poverty is the result of violating the people's right to share in the nation's wealth. They advocate for the universal and unconditional distribution of a basic income rather than occasional cash transfers, and they oppose the conditionalities included in programs for fighting poverty as well as the decision to target specific segments of the population. In their view, financial assistance should not be only for vulnerable people unable to work but also a universal right granted to all individuals, regardless of age, gender, socioeconomic status or other. Furthermore, it should be without any required conditionality or recommended use. In Brazil, this coalition is headed by 
Eduardo Suplicy, who has been a senator since 1991 and is a professor in the Fundação Getúlio Vargas Economics department as well as an economist trained by Michigan State University. He introduced legislation for a national Minimum Income Guarantee Program in 1991, which generated intense debate among the political classes and academic communities. In Mexico, this coalition is represented by actors based in Mexico City, for example, Mexico City's former Mayor Lopez Obrador and his Secretary of Health Asa Cristina Laurell, who together managed to implement the non-means tested Universal Pension (Pensión Alimentaria Ciudadana para Adultos Mayores), which is directed toward city residents over 70 years of age (Jusidman 2010). ${ }^{5}$ At the international level, this coalition is anchored in the Basic Income Earth Network (BIEN). As of July 12,2017 , the organization described on its website that BIEN is an international network which functions as a link between individuals and groups who are committed to or interested in granting an unconditional income to everyone on an individual basis.

Lastly, the members of the 'pro-food security' coalition believe that the core explanations for poverty are hunger and food insecurity. The priority of CCT should center on the right to access food, alongside other measures such as subsidized restaurants, agrarian reform and support for family farming, among others. Even if a hungry person is able to attend school, they will not be able to learn much in class, nor will they be able to work or be healthy or and productive (Takagi 2011, 164). Thus, cash transfers should contribute to food security, i.e. all families should be able to feed themselves with the dignity, regularity, quality and quantity necessary to maintain their physical and mental health (World Food Summit 1996). The 'pro-food security' coalition comprises professionals who are linked to the fight against hunger: economists, agronomists, public health experts, NGOs and representatives of social organizations that address the problem of hunger. The coalition mainly advocates in favor of cash-for-food transfers. The 'pro-food security coalition' argues that people receiving CCT are then constrained to purchase food from small local producers or previously registered merchants. Thus, those transfers foster local and regional food production, which can overcome the vicious cycle of hunger. This coalition was identified only in Brazil. ${ }^{6}$ The 'pro-food security' coalition promotes several institutional advances, which are exemplified by the following events that raised the profile of the topic and strengthened social mobilizations in support of food security measures: the foundation of the Food Security Council (CONSEA) in 1993; the 1st National Conference on Food and Nutrition Security in 1994 and the federal Zero Hunger Program (Fome Zero) in 2003.

\section{Brazilian CCT: institutional change via layering}

Between 1991 and 1997, the 'pro-human capital' and 'pro-unconditional income' coalitions fought for space within the federal legislative arenas. In the Brazilian case, the cash transfer programs entered the political agenda not as a policy linked to the assumptions of human capital, but rather as a policy driven by the belief in the effectiveness of unconditional and universal income.

\section{Legislative project (1991): pro-unconditional income coalition}

In Brazil, the proposal to transfer cash in order to fight poverty was born from a universalist bias. Bill no. 80/1991, known as the Guaranteed Minimum Income Program, was presented in the Senate by Eduardo Suplicy in 1991 and opened the debate on the Brazilian public policy agenda regarding basic cash transfer. This bill proposed providing a universal and unconditional income and focused on solving poverty by sharing the 'wealth of the nation'. According to this proposal, the cash transfer would be implemented gradually, starting with people over the age of 60 . The government would also eliminate most social assistance programs, which were considered wasteful and inefficient (Suplicy 1992). The project was approved unanimously by the Senate in December 1991, although it was not voted on in the Chamber of Deputies. Even though it was blocked by the lower house of Parliament, the proposal generated much debate on the feasibility of cash transfer programs. 
At the time, Mr. Suplicy was an agent operating in three distinct spheres: the professional, the elite and the political (Houtzager 2008). He was a member of the informal network of progressive Brazilian economists, a member of the elite industrialists of São Paulo and the first senator elected by the Workers' Party (PT). Despite being a skilled leader and holding legal authority to introduce bills in the Senate, his coalition lacked the financial resources to put the project into practice.

The 'pro-human capital' coalition is geared toward criticizing the unconditional character of 'Guaranteed Minimum Income' and the initial focus of the program on elderly people. They have suggested that transfers should be initiated for families with school-age children, since children are those who are most likely to break the cycle of poverty (Camargo 1991; Camargo 1993).

The 'pro-unconditional income' coalition changed its strategy when it began to consider implementing a CCT program as a step toward a national program for unconditional income. This coalition then began to act symbiotically with the pro- human capital coalition, although it maintained its fundamental beliefs. Using these programs to advance their interests, the symbiotic efforts toward a pro-unconditional income do not compromise the diffusion of CCT. For many who advocate unconditional income, CCTs such as Bolsa Escola represent a step toward implementing a universal income (Suplicy and Buarque 1997).

\section{Municipal and state initiatives (1994-1997): the pro-human capital coalition}

The unconditional transfer project laid the basis for implementing CCTs by some municipalities and states. However, the 'pro-unconditional income' and the 'pro- human-capital' coalitions both promoted cash transfers. Although they aimed to further develop cash transfer programs at the national level, they encountered strong resistance in the federal arena from political parties and professional groups (i.e. teacher's organizations (Buarque 2009). Their campaigns were essential elements in the creation of programs in states and municipalities. The famous pioneering experiments are those of Campinas (SP) in 1994 and of the Federal District (DF) in 1995. Despite lacking the support of PT's leaders, Cristovam Buarque, then-governor of the Federal District (Buarque 2009), took the initiative to implement the Bolsa Escola program, whose slogan was 'every child in school and quality for every school'. If families did not fulfill these conditions, their benefits could be cut until they restored the frequency of attendance. In Campinas, the Renda Mínima program shared a similar policy design. Suplicy convinced the mayor of Campinas, José Roberto Magalhães Teixeira of the rival Brazilian Social Democracy Party, to implement a CCT program (Suplicy 2011, Coêlho 2012, 80). Although there were differences between the methods for calculating benefits and eligibility criteria, municipalities with different political party administrations quickly emulated these two initiatives throughout the 1990s. Sugiyama (2008) states that ideology and socialized norms played an important role in the diffusion of CCTs among municipalities. $^{7}$

In Brazil, CCTs were created within the limits of other social policies. The 'human capital coalition' worked with existing institutions and did not emerge as an alternative to existing institutions. Although this framework led to less politicization of groups and political constituencies, there was a greater conflict with actors who had historically engaged in activities against poverty (in particular, civil society and social workers). The actors who proposed this new arrangement were dissatisfied with previous policies for fighting poverty, which they judged to be underperforming and inefficient. Houtzager $(2008,58)$ noted that many had decided to distance themselves from the 'longstanding social assistance model', namely the progressive economists specializing in labor markets in particular who favored implanting the municipal CCT program in São Paulo. They hoped that this model would deliver more rapid and visible results in fighting poverty, specifically by overcoming the small-scale projects run by organizations that were fragmented across civil society but nevertheless aimed to meet immediate needs. They were challenging another network of progressives: social workers, many of whom were civil servants working directly with the poor 
as psychiatrists and sociologists (Houtzager 2008). From such a perspective, the emergence of the pro-human capital coalition in Brazil is associated with the following factors: the production of a vast literature on CCT programs, the positive results of local experiences such as those of Brasília and Campinas and, from a human capital perspective, the vocal advocacy of actors in both the political and public spheres who favored fighting poverty.

\section{Federal funding (1997) and Brazilian federal CCTs (2001-2003): pro-human capital coalition}

While initiatives were flourishing at the municipal level, several initiatives from different partisan trends were discussed between 1995 and 1996 in the House of Representatives and in the Senate, which mostly proposed cash transfer programs linked to education. Among the various proposals, President Cardoso signed the bill statutory law no. 9533 of 1997, approving The Minimum Income Guarantee Program (Programa de Garantia de Renda Mínima - PGRM). This program represents federal financial funding support (50\% of spending) to municipalities that conditioned cash transfers to achievements in education. All in all, PGRM was implemented in 1350 municipalities with some small changes to existing institutions. The approval of the 1997 Act is an important milestone in the consolidation of the human capital paradigm.

The emergence of a high-profile paradigm promoting human capital and grounded in a conditional mechanism paved the way to federal actors resuming discussions. In 2000, Constitutional Amendment no. 31 created the Constitutional Fund for Combating and Eradicating Poverty in order to finance actions targeting low-income families. After the approval of this fund, two different ministries implemented CCTs: ${ }^{8}$ Bolsa Escola, a school stipend program linked to the Ministry of Education and Bolsa Alimentação, a nutrition- oriented cash transfer program linked to the Ministry of Health. According to Rocha (2013,117), the Minimum Income Guarantee Program (PGRM) failed to establish a partnership between federal and local governments. Many municipalities, especially the poorest ones, encountered technical and managerial problems. This would explain why federal government relaunched Bolsa Escola in 2001 in order to cover 100\% of the benefits distributed. CCT have gained national coverage and more financial resources. Despite changes in the organization and funding, the adoption of federal programs was accomplished thanks to the practices that had been developed at the local level.

\section{CCT Mexican: institutional change via displacement}

If CCT in Brazil followed from criticism of projects based on unconditional and universal income, in Mexico, there was a shift from generalized subsidy programs to cash transfer programs. The removal of existing rules (mostly the Pronasol and food subsidies) did not take place abruptly. In fact, there was competition between defenders of the new policies (especially the 'pro-humancapital coalition') and promoters of the old institutions and programs who competed until the middle term of Zedillo's government. The latter were unable to prevent the success of the new rules, which gradually dismantled previous programs against poverty.

\section{World Bank working paper (1991): pro-human capital coalition}

The driving principles of this first version of a CCT program were explained in an influential World Bank working paper proposed by Santiago Levy in 1991 (Levy 1991, 84), some years before his nomination as Deputy Minister at the Ministry of Finance. Among the key recommendations of his study were the elimination of all generalized food subsidies (especially tortillas and milk) and placing more emphasis on programs

upholding good behaviors related to education, health and nutrition. In this document, Levy proposed concentrating all resources on a core program along the lines of a Basic Health Care 
Program for the Uninsured Population (PASSPA - Programa de Atención de Servicios de Salud para la Población Abierta). PASSPA was an interinstitutional program headed by the Ministry of Health and Food and involved educational action in the domain of health sanitation and nutrition and was held with mothers and community members (World Bank 1990). The World Bank working paper can be considered a first version of Progresa and the draft of Pro-human capital coalition's core beliefs.

\section{CCT pilots projects (1991-1997) and Progresa (1997): pro-human capital coalition}

The reality test for implementing the concepts related to the promotion of human capital of poor families was the Pilot Program for Nutrition, Food and Health (Programa Alimentación, Nutrición y Salud), which was set in motion between September 1991 and June 1992. Inserted into the Pronasol structure, PNAS was controlled by the Ministry of Health. In addition to free medical services and food distribution, the program included activities to promote community service. In October 1995, a CCT was tested in a pilot project named Programa de Canasta Básica Alimentária para el bienestar de la Família. It was implemented in the state of Campeche and directed toward the beneficiaries of the milk and tortilla program (31,287 families in total). This project could evaluate the feasibility of transferring benefits in cash rather than in kind, which was the practice of PNAS (Ordóñez 2002).

A rival program was developed by the National System for the Integral Development of Family (DIF) in February 1995 under the name Food and Family Nutrition Program (PANF). PANF had similar goals - to improve the nutritional status of the poorest population and to articulate actions regarding education, health and nutrition - and was a formalization of the DIF's ongoing actions. Specifically, it was implemented by DIF in coordination with the DIF state and municipal systems. After less than 1 year of existence, PANF was canceled. The official version states that it had failed to coordinate its actions between the various institutional sectors. However, its dissolution was not due to technical failure or to the inability to achieve the goals of the program but resulted from a radical shift in the government strategy to combat poverty (Chávez-Villasana and Ávila-Curiel 2007, 63).

Daniel Hernández Franco, a former Conapo official and national director of Progresa between 1999 and 2001, stated that the World Bank and IDB assessments between 1993 and 1994 highlighted the ineffectiveness of the policies to fight poverty and the need to invest in human capital: "These assessments would have influenced not only economists in Mexico, but also Cristovam Buarque in Brazil, contributing to the "alignment of the stars" and the introduction of conditional cash transfer policies' (Hernández Franco 2013). If transnational ideas that were well publicized by international agencies played an important role in the adoption of CCT, examining the dynamics of power could explain the triumph of a pro-human capital coalition.

The Zedillo government took almost 3 years to implement a policy to alleviate poverty. During this period, there was no strategy to fight poverty (Brachet-Marquez 2004, 262), which was mostly the result of disputes between the challengers (the pro- human capital coalition) and the advocates of the status quo.

Internal disputes occurred between Levy's groups (pro-human capital coalition) and the group led by Carlos Rojas (the Secretary of Sedesol), which comprised experts that held positions in public institutions in the rural sector and in the Pronasol programs. These disputes in part explain the delay in launching social policies aimed at fighting poverty (Valencia Lomelí and Aguirre 1998). As Levy stated, Progresa was an attempt by the federal government to decouple the performance of social programs from the influence and manipulation of local leaders (Levy 2006, 99), which characterized a source of bureaucratic inertia in trying to stop CCT implementation (Levy and Evelyne 2005, 255). Regarding the previous actors in charge of social programs related 
to Family Development (DIF) and the National Solidarity Program (Pronasol) - which had created the PANF - they found themselves excluded from the creation of Progresa and became 'losers' in the dispute over the direction of the flagship poverty reduction program (Hevia de la Jara 2007, 90).

Indeed, a set of actors comprising the 'pro-human capital' coalition had occupied important positions within Sedesol and the Ministries of Education, Finance and Public Credit, as well as within IMSS, the National Population Council (CONAPO), the National Institute for Statistics and Geography (INEGI), the National Institute of Public Health (INSP) and the Autonomous Technological Institute of Mexico (ITAM) (Levy and Evelyne 2005; Hevia de la Jara 2007). The president himself was an enthusiast of the human capital theory (Valencia Lomelí and Aguirre 1998).

The pilot program that succeeded Progresa contributed to forging and materializing reforms to a series of social programs promoting both the transfer of money and the objectives of investment in human capital. As conveyed by Franco Herdandez,

The pilot proved that, to transform the consumption of families, it was necessary to bring them into the market. However, the system of specialized stores or aid for certain types of products goes against the market. Families are smart and prefer to use money in their own way. (Hernández Franco 2013)

The resources of the actors associated with the pro-human coalition come from the positions of power they enjoyed and their access to the decision-making process for allocating financial resources. To a large extent, the formulation and implementation of the Progresa program was guided by the Ministry of Finance, which determined the budget of social programs and the replacement of generalized subsidies for both a 'health, education and nutrition' package and the rural focus of Progresa. The economist Evelyne Rodríguez, who was involved in the development and implementation of Progresa, remembered that all changes had to go through the Department of Finance following the economic crisis, thus making it a fairly powerful department (Rodríguez 2013). The privileged position of Santiago Levy at the Ministry of Finance enabled his project Progresa to prevail within the government (Valencia Lomelí and Aguirre 1998).

On 8 August 1997, Progresa was finally implemented by fixing a poverty line that considered only half of the poor that Pronasol had identified as being in extreme poverty. Progresa did not need congressional approval but, once implemented, it was systematically approved as part of the federal budget bills that the president submitted to Congress. Aside from the reallocation of resources, the creation of Progresa also implied an institutional rearrangement between ministries and federal agencies. According to Santiago Levy,

Building consensus inside the Cabinet was a gradual process, and the consensus achieved was never complete [...] In the course of various Cabinet discussions over 1995 and 1996, it became clear that - in addition to a shift in thinking about the relationship among food subsidy programs, income transfers and the human capital of the poor - a new approach would require: reallocation of the budget for poverty programs; a reorganization of the administrative apparatus devoted to poverty alleviation; new emphasis on the evaluation and measurement of program results; and the development of a new political relationship between the federal government and beneficiary households. [...] the new program would be implemented instead of and not in addition to previous programs (Levy 2006, 15-16) (author emphasis).

In the case of the Mexican sub-system, institutional change occurred as a gradual process initiated well before implementing Progresa. Unlike the Brazilian case, when the question of human capital entered the agenda, it displaced the old rules of various programs for fighting poverty, notably 
those linked to Pronasol and to food subsidies. Proponents of the old status quo were not well positioned to contain the insurgent efforts of the pro-human capital coalition, which sought to change poverty alleviation policies in order to defend the idea of 'human capital'. Gradual shifts happen when insurgent actors are unable to remove current rules as quickly as they would like (Mahoney and Thelen 2010, 24). Indeed, although the Progresa program replaced the agencies responsible for public food distribution, neither urban stores that sold milk nor the rural network of public stores disappeared (Levy 2006,111).

\section{Mexican federal CCT (1997-2003): pro-human capital coalition}

In the Mexican case, the election of Vicente Fox to the presidency in 2000 put an end to the seventy years of PRI hegemony. Regardless of this historical governmental transition, not only was the Progresa program maintained, but the beneficiaries were also expanded in strongly qualitative and quantitative ways, a development which came to reinforce the cause of the human capital coalition. Renamed Oportunidades in March 2002, Progresa was extended to urban areas, which in turn led to a series of operational changes in the application and selection system. This is one of the major changes made to the program, as it had previously been implemented almost exclusively in rural areas. The continuation and growth of Progresa-Oportunidades is due to highprofile evaluations and popularity as well as to the role of key employees. Many new employees were convinced of its positive effects, whilst some former employees believing in human capital schemes remained in key positions within the new government (Levy 2006, 111).

\section{Policy developments and challenging coalitions: stable subsystems?}

Pro-human capital coalitions were dominant in implementing CCT programs in Mexico and Brazil, as they were able to design institutions that corresponded somewhat to their preferences (Tomazini 2010, 2013). Nevertheless, these CCT programs do not merely reflect the objectives of this coalition. Despite belonging to a more or less stable system where the rules have remained the same for over a decade, nothing can be considered 'automatic, self-perpetuating, selfreinforcing or to about institutional arrangements' (Mahoney and Thelen 2010, 8). In this section, I examine the main outcomes of implementing CCT programs at the federal level and the interactions that programs had with coalitions who challenged their aims.

\section{Brazilian federal CCTs (2003-2004): food security coalition}

With the rise to power of Lula da Silva, all the coalitions that were already present in the Worker's Party (PT) gained important political resources. However, it was the pro-food security coalition who benefited mostly from Lula's victory. This coalition gained a dominant position because it played a primary role during Lula's political trajectory and electoral campaigns. The Fome Zero program constituted his main social proposal. The coalition was initiated by the Institute for Citizenship and endorsed by renowned researchers on food security from the State University of Campinas.

During the first year of Lula's mandate, the federal government introduced a CCT program (Cartão Alimentação) within Fome Zero. It provided money to poor families with certain contingencies attached - such as purchasing food from small producers or previously registered merchants. In contrast to the human capital idea, this program sought to encourage local agriculture and support families' access to food with the dignity, regularity, quality and quantity necessary to maintain their physical and mental health.

This program was more generous than the previous ones, as its budget was twice that of the other CCTs (Rocha 2013, 83). It was implemented incrementally and started in the most deprived regions, such as Brazil's northeast. This represented a major menace to the pro-human capital and 
pro-unconditional income coalitions. An acid rain of criticism from the media, academics and Congress fell daily on the heads of Fome Zero's team and Lula's government. Those actors criticized the fact that hunger, food security and social participation had become central issues in implementing CCTs, as well as Fome Zero's methodology for assessing poverty. As a result, very little time passed before Fome Zero was merged into the background of the Lula government's agenda, which became more concerned with the fusion of CCT programs. Thus, the cause of food security became a sideline issue and lost its central political positions. The Extraordinary Ministry for Food Security and the Fight Against Hunger were abolished and assembled into a larger social ministry (Takagi 2006).

The fusion of the federal CCTs (Bolsa Escola, Bolsa Alimentação and Cartão Alimentação) and Auxílio Gás, which culminated in the Bolsa Família program, followed the precepts laid down by the pro-human capital coalition. The new program aimed to foster the autonomous behavior of poor families by promoting both state and individual family investment in the human capital of future generations.

The ministry adviser outlined both the tension between different actors at the beginning of Bolsa Familia and the difficulty in justifying the program's conditionalities: There is a certain tension between those who were talking about "income and citizenship", as well a tension between those focused on the right to food security. There were basically three groups around the table: one talking about citizenship, another about food and nutritional security, and the conditioned cash transfers group (people linked both to education and health). (Campos Filho 2009)

While ideational conflict and opposing federal CCT preferences determined the overall direction of policy change, the argument for rationalizing existing programs continued to reverberate.

There were different understandings in the government about what is or what should be a priority, but - inside the mind of the executive (i.e., President Lula) - there has never been such a change. The decision to unify the income transfers was taken with the idea of giving greater rationality to the many programs that existed and, at the same time, expanding them. (Takagi 2009)

Patrus Ananias, former Minister of Social Development, pointed out 'Bolsa Familia assumes the centrality of the social protection network when the material conditions are given to promote a more articulated policy. Therefore, the income transfer policy organizes, but does not shift the focus of the government strategy in fighting poverty' (Ananias 2009) (author emphasis). A series of low-profile processes has slowly transformed the nature of Brazil's welfare regime. As for the layering process that involves multiplying CCT programs, the dominant human capital paradigm provides a strong ideological rationale for this process and for the crusade against the unconditionality or food security ideas.

The actors associated with the pro-human ideas exercise decisive influence not only in the international arena but also within the state bureaucracies. The presence of federal policy-makers in the Lula government, who came especially from southern and southeastern cities, can also explain this policy option. According to my classification, these actors were members of the prohuman capital coalition due to their experiences with the conditional transfer programs implemented in their municipalities.

Regarding the influence of international organizations, the World Bank sent its experts to Brazil for technical support, with Progresa's designers also being invited. Following a meeting in March 2003 with Santiago Levy and James Wolfenson, the World Bank president at the time, Lula formally requested that the Social Assistance Minister prepared an action (Lindert et al. 2007, 13). A race for defining the area of influence had started between two main international borrowers. 
According to Rodríguez (2013), the Brazilian model was based on different foundations than those of the Mexican model:

Since the IDB was the creditor of the Progresa program, the World Bank would have rushed to take the credit and visibility of the program to be initiated in Brazil. [...] I thought they already had a list of programs that would be replaced, but it did not happen.

Indeed, it seems that the Brazilian channel of institutional overlap is not the one recommended by organizations disseminating and proposing similar policies for developing countries.

The decision about where to institutionally place the program also reveals the various conflicts of viewpoints that were present at the beginning of the Lula government. In order to avoid a guardianship dispute between ministries, it was not allocated to any ministry (Takagi 2006, 173). Lula's administration assigned Bolsa Família to an Executive Secretariat linked to the President rather than to the existing Ministry of Social Assistance, which had extensive relations with social workers. In addition to preventing interministerial disputes, the executive power was seeking to avoid interfering with primeiro damismo ${ }^{9}$ and collusion among individual interests (Camara 2013).

Likewise, the pro-human capital coalition in Mexico had more political and financial resources specifically those allocated by the Ministry of Finance and the Casa Civil. Powerful actors were especially opposed to policies aimed at food security transfers (Betto 2009).

\section{Brazilian legislative initiative, law no. 10,835 (2004): pro-unconditional income coalition}

At the same time that the Bolsa-Família program was adopted, another law was ratified to guarantee a universal basic income for all citizens, regardless of their social origin, income level, gender, religious beliefs or any other criteria. According to the law of 8 January 2004 (no. 10,835), authored by Senator Eduardo Suplicy, all legal residents - whether Brazilian or not - should receive a monetary benefit that sufficiently covers their minimum expenses for food, education and health. However, more than 10 years and three elections cycles after its approval, the law is still not in effect. The law had proposed implementing the program 'in stages' and 'at the discretion of the Executive branch, giving priority to the neediest segments of the population' while 'taking into consideration the country's level of development and budget possibilities' (Brasil 2004). Although the law has been held up, actors in the unconditional transfer coalition still consider the 2004 law to be an important step in gradually converting Bolsa-Família into an unconditional program (Suplicy 2011).

The approval of this law provides evidence of the pro-unconditional income coalition's increased presence and effectiveness in influencing CCT policy. Furthermore, unlike Mexico, conditionalities do not represent a central feature of the Brazilian CCT program.

There is a Brazilian approach to conditionality - which is a non-punitive approach. We take advantage of all data produced by monitoring conditionalities to identify the family's vulnerabilities. However, we would not exclude the family because of their vulnerability, which would let it get worse. (Camara 2013)

Thus, it may be that actors linked to the cause of unprocessed universal income had some influence in producing this Brazilian non-punitive model of non-compliance with conditionalities. Even while supporting Bolsa Família, this coalition is active and successful in its quest to implement a program of unconditional income.

\section{Mexican federal CCT (2006): pro-unconditional income coalition}


In 2003, the government of Mexico City implemented a Universal Pension (Pension Alimentária Ciudadana de Adultos Mayores, PACAM). This is a non-means-tested and non-contributory program directed at residents who are 70 years old or more, as defined in the law of 18 November 2003. Pablo Yanes Rizo, former Director of the agency in charge of developing social programs in Mexico City, defined the difference between the local and federal policies: 'The Mexico City program is built according to the perspective that all have the right to an income. Opportunidades was built with a view toward human capital, meaning with the thought of inserting the beneficiary into the labor market (Yanes Rizo 2010)'.

The adoption of the law that established the program was the subject of lively discussion in the Legislative Assembly. According to Levy (Levy 2006, 89), the Universal Pension in Mexico City contributed to opening up the discussion about social programs not related to food. It can be inferred that the debate on cash transfers in Mexico took a very clear partisan turn, particularly with respect to the left-right cleavage. However, in view of the program's popularity, governors from all political boards sought to replicate (the universal pension) model of income transfers to the elderly.

A number of criticisms were made regarding the universality of PACAM; they accused it especially of being populist and clientelist (Combes 2007). President Vicente Fox, in a speech during his radio show, frontally attacked Mexico City's program, emphasizing its 'unfairness' in being funded by taxing those who work (La Jornada, 14 March 2005).

Despite these criticisms, President Fox himself put in place a similar measure in 2006. The measure consisted of financial aid for people over 70 living in cities with more than 10,000 inhabitants and for the family members of Oportunidades' beneficiaries. This new element of the program was not intended or justified by Oportunidades' objectives, strategies and lines of action, nor was it the result of recommendations or ratings from agencies or universities (Hevia de la Jara 2007). The new component of Oportunidades (70 y Más) represents an expansion of people targeted to include elderly people. It combines elements of the federal and Mexico City programs and follows a rationale apart from the human capital theory.

As the 'human capital' coalition turned into 'institutional defenders' of the CCT program, it adopted a defensive posture and strategically modified structures in order to preserve them. The new elements in Oportunidades were thus produced by the interaction between the institutional defenders and the unconditional income coalitions. The political actors of the 'human capital' coalition changed some rules of Oportunidades in order to address the needs of elderly people, but they retained the characteristics of their cognitive matrix. During this period, the "human capital' coalition can be viewed as an opportunistic agent, in the sense that it explored the ambiguities and applications of the rules in force and sought to recreate these rules in ways that diverged from the intentions of the program's original framers.

\section{Conclusion}

This article has offered a dynamic understanding of the origins and development of policies and social innovations in Brazil and Mexico. Although the results of the institutional changes are similar, institutional changes that led to the creation of CCTs did not share the same underlying process. They are instead different state reforms that took place in analytically nonequivalent contexts, in which the different causal mechanisms may have led to the same results. The article identifies three endogenous triggers: (1) the rise of a dominant advocacy coalition in favor of an ideology promoting human capital as a key factor in the formation of national CCT programs in Brazil and Mexico; (2) patterns of change (layering and displacement, in Brazil and Mexico) and strategies adopted by these advocacy coalitions are different in the two countries (subversive and insurrectional, respectively); (3) despite being marginal in CCT subsystems, other coalitions (pro- 
unconditional income and pro-food security) struggle for position and may act in either a defiant or symbiotic manner.

The pro-human capital advocacy coalitions were crucial in paving the way for CCT adoptions. These coalitions underwent a process of change that was incremental but cumulatively may be transformative. In Brazil, Bolsa Família represents a breakdown in social policy: it monopolizes policy directed toward the poorest sectors of society in a country that, unexpectedly, has a "huge bureaucratic apparatus of institutional welfare' (Draibe 2006, 139-40). This extensive apparatus consists of powerful actors who were unable to prevent the addition of new elements related to the precepts of human capital. The change in the Brazilian case corresponds to the layering type: it took place by adding new institutions and rules on top of or adjacent to existing policies and caused significant change over time. The pro-human capital coalition was one of the agents of change, being a subversive actor seeking to transform the system from within. They did so specifically by exploiting small openings that had first emerged in the most economically developed municipalities, followed by an escalation of CCT proposals in the Congress and executive agencies.

In Mexico, the pro-human capital coalition faced a more permeable power structure due to a political-economic crisis. The change occurred by displacement and by gradually replacing old rules with new ones. In 1997, the defenders of the status quo actors failed to obtain the institutional or extra-institutional means to block the pro-human capital coalition's proposed changes. Nonetheless, CCT are also the result of 'ambiguous agreements' among actors who can coordinate institutional resources, even if they differ on the substantive goals (Schickler 2001; Palier 2002). As CCT in Brazil and Mexico is associated with different causes, competing interpretations of the same program can mobilize quite different coalitions. Despite being marginal in CCT subsystems, the pro-unconditional income and pro-food security coalitions each struggling for a niche, may act defiantly or symbiotically against the dominant coalition (prohuman capital).

\section{Notes}

1. Initially know as Progresa, then Oportunidades and now, the program was renamed Prospera in 2014.

2. Interviews took place in Brazil (May-June 2009, April 2011, September 2013) and Mexico (January-February 2010, January-February 2013), with an average of one and a half hours' duration.

3. Rector of the University of Brasilia, he created the Center for Contemporary Brazilian Studies in 1986, where he created Bolsa-Escola program, a cash conditional transfer seen as an instrument of struggle against both poverty, social exclusion and child labor. In 1995, Buarque - then a member of the Workers' Party (PT) - became governor of the Federal District and set up the Bolsa-Escola program with the slogan 'Every child in the school and all School of quality'.

4. LevywasDeputyMinisterattheMinistryofFinanceandPublicCreditofMexicofrom1994 to 2000. He is often presented as the main architect of Progresa-Oportunidades. He advised several international organizations - especially the Inter-American Developement Bank - and held several teaching position at the Instituto Tecnológico Autónomo of Mexico and at Boston University.

5. The age range was lowered to 68 years in 2009.

6. Although I could identify actors in Mexico who advocated for distributing food and maintaining general food subsidies, these actors did not constitute a Mexican coalition advocating cash transfers for purchasing local foods in the name of food security, such as what occurred in Brazil.

7. In 1996, the federal government implemented the program for the Eradication of Child Labor (Programa para a Eradicação do Trabalho Infantil - PETI) in regions with the highest concentration of children working in inhumane conditions.

8. Another financial benefit (but not a conditional one) was created in 2002: the cooking fuel supplement scheme (Auxílio Gás), administered by the Ministry of Mines and Energy. 
9. 'Primeiro-damismo' is a term used to describe the practice of social assistance policies which operate through funds allotted to the wives of governors and/or mayors for financing social projects.

\section{Disclosure statement}

No potential conflict of interest was reported by the author. Funding

This work was supported by the Campus France [Eiffel Excellence Scholarship Programme] and Coordenação de Aperfeiçoamento de Pessoal de Nível Superior [CAPES].

Notes on contributor

Carla Tomazini is currently an assistant professor in the Department of Law and Political Science at the University of Versailles Saint-Quentin-en-Yvelines, France. Her research interests are in the field of comparative politics, with a focus on political institutions and the Welfare State.

\section{Interviews}

Ananias, P. 2009. Former Minister of Social Development (MDS). June 5. Statement received by email.

Betto, F. (Carlos Alberto Libânio Christo). 2009. Special Adviser to the President (2003-2004). May 6. Statement received by email.

Buarque, C. 2009. Senator and former governor of the Federal District, April 29. Brasília. Camara, B. 2013. Advisor in the cabinet of the Ministry of Social Development. 15 August. Brasília.

Campos Filho, A. C. 2009. Assessor in the cabinet of the Ministry of Social Development, April 30. Brasília.

Hernández Franco, D. 2013. Former national director of Progresa-Oportunidades, 23 February. Mexico City.

Jusidman, C. 2010. President of INCIDE Social, 4 February. Mexico City.

Rodríguez, E. 2013. Former treasurer of Mexico and former general director of planning and budget for agriculture, social development and environment at the Ministry of Finance. February 25. Mexico City.

Suplicy, E. 2011. Senator, Brazilian Senate. April 13. Brasília.

Takagi, M. 2009. Former official at the Ministry of Food Security and Fight Against Hunger, Secretary for Food Security in MDS, May 22. Statement received by email.

Yanes Rizo, P. 2010, Former Director at Mexico City's Council for the Evaluation of Social Policy. February 8. Mexico City.

\section{References}

Brachet-Marquez, V. 2004. “El Estado Benefactor mexicano: nacimiento, auge y declive (1822- 2000)." In La pobreza en México y el mundo: realidades y desafíos, edited by J. Boltvinik and D. Araceli. México: Siglo XXI.

Brasil. 2004. Avaliação Do Programa Bolsa-Alimentação: Primeira Fase. Brasília: Ministério da Saúde. 
Brière, B. D. L., and L. B. Rawlings. 2006. Examining Conditional Cash Transfer Programs: A Role for Increased Social Inclusion? World Bank Social Protection Discussion Paper no. 0603. Washington, D.C.: World Bank.

Camargo, J. 1993. “Os Miseráveis.” Folha de São Paulo, March 27.

Camargo, J. M. 1991. “Pobreza E Garantia de Renda Mínima.” Folha de São Paulo. December 26.

Carnes, M. E., I. Mares, 2007. “The Welfare State in Global Perspective." In Handbook of Comparative Politics, edited by Carles Boix, Susan Stokes. Oxford: Oxford University Press.

Coêlho, D. B. 2012. "Political Competition and the Diffusion of Conditional Cash Transfers in Brazil." Brazilian Political Science Review 6: 2. doi:10.1590/S1981-38212012000200003.

Cohen, E., and R. Franco. 2006. "Los Programas de Transferencias Con Corresponsabilidad En América Latina: Similitudes Y Diferencias." In Transferencias Con Corresponsabilidad Una Mirada Latinoamericana, edited by E. Cohen and R. Franco. México: Flacso, Sedesol.

Combes, H. 2007. “La Guerre Des Mots Dans La Transition Mexicaine.” Mots. Les Langages Du Politique 85: 51-64.

Draibe, S. M. 2006. “Brasil: Bolsa Escola Y Bolsa Família." Caderno de Pesquisa, Núcleo de Estudos de Políticas Públicas da UNICAMP, no 76: 1-43.

ECLAC. 2017. Social Development Division. Non-Contributory Social Protection Programms Database. Accessed July 12 2017. http://dds.cepal.org/bdptc/en/

Esping-Andersen, G. 1990. The Three Worlds of Welfare Capitalism. Princeton: Princeton University Press.

Hall, A. 2006. "From Fome Zero to Bolsa Família: Social Policies and Poverty Alleviation under Lula." Journal of Latin American Studies 38 (4): 689-709. doi:10.1017/S0022216X0600157X.

Handa, S., and B. Davis. 2006. "The Experience of Conditional Cash Transfers in Latin America and the Caribbean." Working Paper 06-07. Agricultural and Development Economics

Division of the Food and Agriculture Organization of the United Nations (FAO - ESA). Hevia de la Jara, P 2007. El Programa Oportunidades Y La Construccion de Ciudadania. Doctorado en Antropología, México, D.F.: Ciesas.

Houtzager, P. 2008. "The Silent Revolution in Anti-Poverty Programmes - Minimum Income Guarantees in Brazil." IDS Bulletin 38: 6.

Huber, E., and J. D. Stephens. 2001. Development and Crisis of the Welfare State: Parties and Policies in Global Markets. Chicago: University of Chicago Press.

Chávez-Villasana, A. and A. Ávila-Curiel. 2007. “Pertinencia de Las Normas Y Ordenamientos Actuales Vinculados Con La Nutrición Y El Abasto.” México: Instituto Nacional de La Nutrición Salvador Zubirán.

Levy, S. 1991. "Poverty Alleviation in Mexico." Policy, Research, and External Affairs working papers WPS 679. Country Operations. Washington, D.C.: World Bank.

Levy, S. 2006. Progress against Poverty: Sustaining Mexico's Progresa-Oportunidades Program. Washington, D.C.: Brookings Institution Press. 
Levy, S., and R. Evelyne. 2005. "El Programa de Educación, Salud Y Alimentación, PROGRESA- Programa de Desarrollo Humano Oportunidades." In Ensayos Sobre El Desarrollo Económico Y Social de México, edited by Santiago Levy. México: FCE.

Lindert, K., A. Linder, J. Hobbs, and D. B. Bénédicte. 2007. “The Nuts and Bolts of Brazil's Bolsa Família Program: Implementing Conditional Cash Transfers in a Decentralized Context."

World Bank Social Protection Discussion Paper no. 0709. Washington, D.C.: -Word Bank. Lindert, K., and V. Vincensini. 2010. Social Policy, Perceptions and the Press: An Analysis of the Media's Treatment of CCTs in Brazil. World Bank Social Protection Discussion Paper no. 1008. Washington, D.C.: World Bank.

Mahoney, J., and K. Thelen, eds. 2010. Explaining Institutional Change: Ambiguity, Agency, and Power. Cambridge: Cambridge University Press.

MDS. 2017. "Secretaria de Avaliação E Gestão Da Informação. Ministério Do Desenvolvimento Social." Accessed July 12 2017. http://aplicacoes.mds.gov.br/sagi/miv/miv.php.

Ordóñez, G. M. B. 2002. La Política Social Y El Combate a La Pobreza En México. Mexico, D.F.: UNAM.

Palier, B. 2002. Gouverner la sécurité sociale: les réformes du système français de protection sociale depuis 1945. Paris: Presses universitaires de France.

Rocha, S. 2013. Transferências de Renda No Brasil. O Fim Da Pobreza? Rio de Janeiro: Elsevier.

Sabatier, P. 1999. "The Advocacy Coalition Framework: An Assessment" In Theories of the Policy Process. edited by Paul Sabatier. Boulder: Westview Press.

Sabatier, P., and C. M. Weible. 2007. "The Advocacy Coalition: Innovation and Clarifications." In Theories of the Policy Process. edited by Paul Sabatier. Boulder, CO: Westview Press.

Sabatier, P., and H. C. Jenkins-Smith. 1993. Policy Change and Learning: An Advocacy Coalition Approach. Boulder, CO: Westview Press.

Schickler, E. 2001. Disjointed Pluralism: Institutional Innovation and the Development of the U.S. Congress. Princeton: Princeton University Press.SEDESOL. 2017. "Secretaría de Desarrollo Social." Accessed July 12 2017. https://www.gob.mx/prospera/documentos/que-es-prospera

Streeck, W., and K. Thelen, eds. 2005. Institutional Changes in Advanced Political Economies. Oxford: Oxford University Press.

World Food Summit. 1996. Rome Declaration on World Food Security. Accessed July 122017. http://www.fao.org/docrep/003/w3613e/w3613e00.htm

Sugiyama, Natasha. 2008. “Ideology And Networks: The Politics Of Social Policy Diffusion In Brazil." Latin American Research Review 43 (3): 82-108.

Suplicy, E. 1992. Programa de Garantia de Renda Mínima. Brasília: Senado Federal.

Suplicy, E., and C. Buarque. 1997. “Garantia de Renda Mínima Para Erradicar a Pobreza: O Debate E a Experiência Brasileiros.” Estudos Avançados 11 (30): 79-93.

Takagi, M. 2006. A Implantação Da Política de Segurança Alimentar E Nutricional No Brasil: Seus Limites E Desafios. Campinas: Universidade Estadual de Campinas - Instituto de Economia. 
Takagi, M. 2011. "Food and Nutrition Security and Cash Transfer Programs." In The Fome Zero (Zero Hunger) Program: The Brazilian Experience, edited by José Graziano da Silva, Mauro Del Grossi, and Caio Galvão de França. Brasília: Ministry of Agrarian Development.

Thelen, K. 2003. "How Institutions Evolve. The Political Economy of Skills in Germany, Britain, the United States, and Japan." In Comparative Historical Analysis in the Social Sciences, edited by J. Mahoney and D. Rueschemeyer, 208-240. New York: Cambridge University Press.

Tomazini, C. 2010. “As Coalizões de Causa Em Torno Das Políticas de Transferências Condicionadas: Olhar Cruzado Brasil-México." Carta Internacional 5(2): 37-55.

Tomazini, C. 2013. "Les Conflits Autour Des Politiques de Transferts Monétaires : Les Coalitions de Causes et Le Renforcement Du Paradigme « Capital Humain » Au Brésil et Au Mexique." In L'analyse Des Politiques Publiques Au Brésil. edited by M. R. Lukic and C. Tomazini. Paris: L'Harmattan. Logiques Politiques.

Valencia Lomelí, E., and R. R. Aguirre. 1998. Discursos, Acciones Y Controversias de La Política Gubernamental Frente a La Pobreza. In Los Rostros de La Pobreza: El Debate. edited by R. Gallardo and J. Osorio. México, DF: ITESO-UIA.

Weyland, K. 2004. "Learning from Foreign Models in Latin American Policy Reform: An Introduction." In Learning from Foreign Models in Latin American Policy Reform. Washington, D.C.: Woodrow Wilson Center Press.

Weyland, K. 2006. Bounded Rationality and Policy Diffusion: Social Sector Reform in Latin America. Princeton: Princeton University Press.

World Bank. 1990. Mexico - Basic Health Care Project. Washington, D.C.: World Bank. Accessed July 12 2017. http://documents.worldbank.org/curated/en/1990/11/737170/mexico- basic-health-careproject.

\section{Table I.}


Table 1. Advocacy coalitions and beliefs associated with poverty.

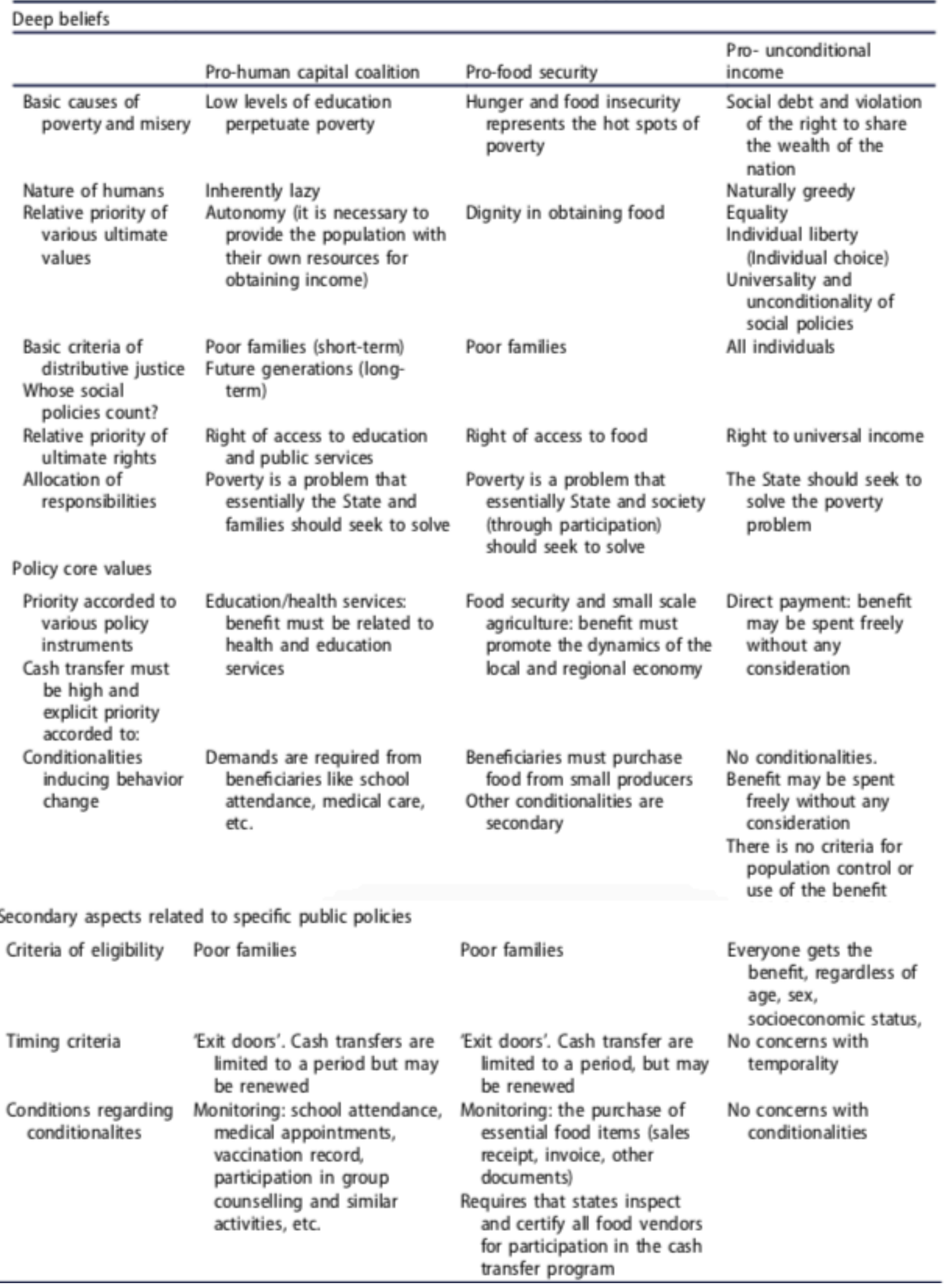

